\title{
Bacteriological status of fish marketed in Beni-Suef City
}

\author{
F. A. Khalafalla*, Fatma H. M. Ali, A. H. Abdel-Azeem \\ Department of Food Hygiene, Faculty of Veterinary Medicine, Beni-Suef University
}

\begin{abstract}
This study was carried out to evaluate the bacteriological status of fresh Tilapia nilotica, fresh Clarias lazera, frozen Mackerel and smoked Herring fish marketed in Beni-Suef City. The collected samples were examined for total bacterial count, coli form (MPN), faecal coli forms (MPN), E. coli (MPN), Staphylococcus aureus count, total proteolytic count, total lipolytic count, Aeromonas count and Pseudomonas count, as well as the isolation of E. coli, Staphylococcus aureus, Aeromonas hydrophila, Pseudomonas aeruginosa, Yersinia enterocolitica and Listeria monocytogenes. Most of the examined samples were within the permissible limits recommended by EOS and ICMSF, few samples of fresh Clarias lazera exceeded the recommended limits. The economic importance and public health significance of the isolated organisms were discussed.
\end{abstract}

Fish is an important protein source in many countries all over the world including Egypt. It is providing human by essential dietary protein of a high nutritive value, cardiovascular-protective omega-3 polyunsaturated fatty acids, essential minerals (phosphorus and calcium), vitamins (especially vitamin A), iodine, fluorine and appreciable amounts of cobalt, magnesium, iron, copper and very low quantities of cholesterol.

The microbial status of seafood after catch is closely related to the environmental conditions and microbiological quality of the water, these factors include water temperature, salt content, distance between the point of catch and polluted areas, natural occurrence of bacteria in the water, ingestion of food by fish, methods of catch and chilling, and post-harvest handling or processing conditions.

The rate of fish deterioration is highly temperature dependent and can be inhibited by the use of low storage temperature; therefore, it was advised by the need for careful attention to temperature control and the reduction of the time elapsing between fishing and consumption (Feldhusen, 2000 and Sivertsvik et al., 2002). Freezing is one of the most appropriate preservation technologies of food used for fish. In addition to, the using of freezing and cold storage in fish preservation are more efficient than the other most traditional methods such as salting, smoking and drying (Jayasinghe et al., 1996).

Fish can acquire pathogenic microorganisms or toxins from natural aquatic

\footnotetext{
* Corresponding author. Tel.: +20 082 2322066; Fax: +20 0822327982

E-mail address: khalafalla@bsu.edu.eg

(Fathy A. khalafalla)
}

environment, sewage, contaminated harvesting area as well as from workers, utensils and equipment during harvesting, processing, distribution and food preparation (National Academy of Science, 1985). Contaminated seafood has been implicated in food borne outbreaks in many countries; the majority of them have been caused by bacteria, viruses, histamine and marine biotoxins.

There is an increasing demand for fish and fish products around the world, although, there is substantial evidence that fish and seafood are high on the list of foods associated with outbreaks of food borne diseases. So, it became important to pay more attention to seafood safety and seafood-related diseases. Therefore, this work was carried out to evaluate the bacteriological status of the most popular consumed fishes that marketed in Beni-Suef City (fresh Tilapia nilotica, fresh Clarias lazera, frozen Mackerel and smoked Herring fish).

\section{Materials and methods}

Collection of the samples. A total of 120 fish samples were randomly collected from different fish markets at Beni-Seuf City; 30 each of fresh Tilapia nilotica, fresh Clarias lazera, frozen Mackerel and hot smoked Herring fish. Five samples were collected weekly. Organoleptic examination all of the collected samples were apparently healthy. The collected samples were identified and separately wrapped in sterile polyethylene bags and directly transferred in sterile icebox to the laboratory without delay to be examined within 6 hours after collection.

Preparation of the samples. Preparation of the muscle samples was carried out according to the muscle maceration technique recommended by (ICMSF, 1978).

Bacteriological techniques. 
Determination of aerobic plate count at $35^{\circ} \mathrm{C}$ (APC). The pouring plate technique recommended by (AOAC, 1990) was applied.

Coli forms, faecal coli forms and $E$. coli (MPN). The applied technique was the three tubes method (MPN) recommended by (AOAC, 1990).

Isolation and identification of $E$. coli biotype I (true fecal type). The isolates were microscopically and biochemically identified according to the methods recommended by (AOAC, 1990).

Determination of Staphylococcus aureus count. The technique of Staphylococcus aureus count was performed according to (APHA, 1992).

Isolation and identification of coagulase positive Staphylococcus aureus. The isolates were identified according to the recommended technique by (APHA, 1992).

Pseudomonas / Aeromonas count. The recommended technique by (Pireson et al., 1970) was applied.

Isolation and identification of Aeromonas hydrophila and Pseudomonas aeruginosa. The isolates were identified microscopically and biochemically according to the recommended technique by (Koneman et al., 1994).

Isolation of Yersinia enterocolitica. The applied technique was that recommended by (APHA, 1992).

Isolation and identification of Listeria monocytogenes. The applied technique was that recommended by FAO, (1992) using the towsteps enrichment method.

\section{Bacterial counts.}

\section{Results and Discussion}

Fresh Tilapia nilotica. The illustrated data in Table (1) revealed that the mean values of APC at $35^{\circ} \mathrm{C}$, coli forms, faecal coli forms and E. coli (MPN), Staph. aureus, proteolytic, lipolytic, Aeromonas and Pseudomonas counts in muscle samples of Tilapia nilotica were $5.9 \times 10^{4}, 2.8 \times$ $10^{4}, 2.1 \times 10^{3}, 1.0 \times 10^{3}, 4.8 \times 10^{2}, 1.2 \times 10^{4}, 2.9$ $\times 10^{4}, 2.6 \times 10^{2}$ and $5.7 \times 10^{2}$ organisms/g muscle; respectively.

High figures were reported by (Abo El Alla, 2000; Abdel-Rahman et al., 2004; Ali and Ibrahim 2004). While, low figures were obtained by (Mahmoud, 1999; Tzikas et al., 2007). Nearly similar results were recorded by (Agnese et al., 2001; Martins et al., 2002),

The high data obtained in examined fresh fish could be attributed to high temperature of storage during marketing for long time, the using of unhygienic utensils and equipment, as well as the current use of unhygienic water during marketing. In addition to, polluted water and mud from which the fish were caught play an important role in increasing the rate of contamination of fish flesh, this agrees with that reported by Fawzy et al., (1981); Khalafalla, (1988).

Fresh Clarias lazera. The data in Table (1) showed that the mean values of APC at $35^{\circ} \mathrm{C}$, coli forms, faecal coli forms and E. coli (MPN), Staph. aureus, proteolytic, lipolytic, Aeromonas and Pseudomonas counts in muscle samples of Clarias lazera were $8.8 \times 10^{4}, 4.0 \times 10^{4}, 2.0 \times$ $10^{4}, 7.8 \times 10^{3}, 1.5 \times 10^{3}, 2.0 \times 10^{4}, 2.7 \times 10^{4}, 9.9$ $\mathrm{x} 10^{2}$ and $1.9 \times 10^{3}$ organisms/g muscle; respectively. High results were obtained by (Khalafalla, 1988; El-Atabany 1990). Low result was recorded by (Mousa and Mahmoud 1997; Mahmoud, 1999).

It was clear that the highest aerobic plate count was reported in fresh Clarias lazera, which could be attributed to the heavily polluted water inhabited by such fish. In addition to that, Clarias lazera are dirty feeders and the absence of scales gives more chance for surface contaminants to penetrate rapidly into fish muscles, this in accordance with that reported by (Khalafalla, 1988).

Frozen Mackerel. The recorded results in Table (1) revealed that the mean values of APC at 35 ${ }^{\circ} \mathrm{C}$, coli forms, faecal coli forms and E. coli (MPN), Staph. aureus, proteolytic, lipolytic, Aeromonas and Pseudomonas counts in muscle samples of frozen Mackerel were $2.8 \times 10^{4}, 4.9$, $1.8,0.7,2.4 \times 10^{2}, 2.3 \times 10^{3}, 2.9 \times 10^{3}, 9.0 \times 10$ and $3.3 \times 10$ organisms/g muscle; respectively. High figures were recorded by (Hwang et al., 2004; Pacheco et al., 2004; Geevarethnam et al., 2008). While, nearly similar results were reported by (Pensrie et al., 1991; El-Bakkly, 1997).

Low results were reported in frozen fishes as compared with fresh fish could be attributed to the inhibitory or the sub lethal effect of freezing and frozen storage on bacteria. This could be confirmed by that mentioned by (Magnusson and Martinsdottir, 1995) who stated that the frozen storage of fish at $-25{ }^{\circ} \mathrm{C}$ leading to great reduction in the bacterial counts; 23 and 50 weeks of storage resulted in $80 \%$ and $91 \%$ bacterial counts, respectively.

Smoked Herring fish. The obtained data in Table (1) showed that the mean values of APC at $35{ }^{\circ} \mathrm{C}$, coli forms, faecal coli forms and E. coli 
(MPN), Staph. aureus, proteolytic, lipolytic, Aeromonas and Pseudomonas counts in muscle samples of smoked Herring were $3.9 \times 10^{3}, 0.6$, $<3,<3,1.4 \times 10^{2}, 2.8 \times 10^{2}, 3.4 \times 10^{2}, 3.3$ and $1.3 \times 10$ organisms/g muscle; respectively. High results were obtained by (Bastawrows et al., 2000; Basti et al., 2006). On the other hand, low counts were reported by (Gonzalez Rodriguez et al., 2002).

The mean values in smoked Herring were low as compared with fresh fishes and this could be attributed to the inhibitory effect of salt in addition to the bacteriostatic and bactericidal effect of smoke compounds during the preparation, this held the view reported by El(Akeel, 1988).

\section{Bacterial isolation.}

Escherichia coli (biotype I). From the results represented in Table (2), it can be concluded that the incidence of $E$. coli in the examined muscle samples of Tilapia nilotica and Clarias lazera were 40 and $53.3 \%$, respectively. In addition, E. coli could not be recorded in the examined muscle samples of frozen Mackerel and smoked Herring.

High figure was recorded by (Silva et al., 2002). While, low figures were recorded by (Youssef et al., 1992; Agnese et al., 2001). Similar figures were recorded by (Gonzalez Rodriguez et al., 2002; Papadopoulou et al., 2007).

In this respect, EOS (1-889/2005) recommended that frozen fishes should be free from E. coli. As well as EOS $(288 / 2005)$ recommended that smoked fishes should be free from E. coli. So, all of the frozen Mackerel samples $(100 \%)$ and all of the smoked Herring samples were within the Egyptian limits.

Staphylococcus aureus (coagulase positive). The results obtained in Table (2) revealed that the incidence of isolation of Staphylococcus aureus from the examined muscle samples of Tilapia nilotica, Clarias lazera, frozen Mackerel and smoked Herring were 26.6, 33.3, 6.6 and 10 $\%$, respectively.

Nearly similar results of Staphylococcus aureus were obtained by (Ayulo et al., 1994; Papadopoulou et al., 2007). On the contrary, (Youssef et al., 1992) could not isolate it from Tilapia nilotica. Low results were recorded by (Rodma et al., 1991). EOS, (288/2005) stated that smoked fish should be free from Coagulase positive Staphylococcus aureus, so $10 \%$ of the examined smoked Herring were not within the permissible limits recommended by EOS,
(288/2005). In this subject, sea foods are free from Staphylococcus aureus and contamination takes place upon handling (Bryan, 1980).

Humans are common carriers of Staphylococcus aureus in the nose, throat and in skin infections and can easily be transferred to food through handling, this held the view reported by (Pereira et al., 1994). Staphylococcus food poisoning is characterized by nausea, vomiting, abdominal pain, and prostration, often with diarrhea but without fever, approximately one to 6 hours after ingestion of contaminated food. Although many patients usually completely recover after 24 hours without specific therapy and show a low overall case-fatality ratio, the symptoms are serious enough for up to $10 \%$ of case to be admitted to hospital (Eley, 1992).

Aeromonas hydrophila. From the obtained results in Table (2), it could be concluded that the incidence of Aeromonas hydrophila in examined muscle samples of Tilapia nilotica and Clarias lazera were 20 and $16.6 \%$, respectively.

High figures in fresh fish were recorded by (Abo El Alla, 2000; Davies et al., 2001; Thayumanavan et al., 2003; Papadopoulou et al., 2007). On the contrary, low results were recorded by (Kumar et al., 2000; Radu et al., 2003). Nearly similar results were recorded by (Ali and Ibrahim, 2004).

On the contrary, Aeromonas hydrophila could not be isolated from the examined muscle samples of frozen Mackerel and smoked Herring; this was illustrated in Table (2).

Aeromonas spp. (principally Aeromonas hydrophila) are considered emerging food borne pathogens that are associated with septicemia, gastroenteritis, enterocolitis and wound infection in humans, this was reported by (Janda, 1991).

Pseudomonas aeruginosa. The results represented in Table (2) revealed that the incidence of Pseudomonas aeruginosa in examined muscle samples of Tilapia nilotica and Clarias lazera were 16.6 and $13.3 \%$, respectively. Low results were obtained by Mahmoud, (1990) and High figure was obtained by Ali and Ibrahim, (2004). In this respect, nearly similar result was reported by Abdel Rahman et al., (2004). The same Table revealed that Pseudomonas aeruginosa could not be detected in frozen Mackerel and smoked Herring samples.

Pseudomonades are a good spoilage index in fishes and a marker for fish carcass deterioration, this held the view reported by Pacheco et al., 
(2004).

Yersinia enterocolitica. From the results obtained in Table (2) it can be concluded that the incidence of isolation of Yersinia enterocolitica from the examined muscle samples of Tilapia nilotica, Clarias lazera, frozen Mackerel and smoked Herring were 23.3, 30, 16.6 and $10 \%$, respectively. Nearly similar result of in fresh fish was recorded by (Papadopoulou et al., 2007). While, high result in fresh fish was obtained by (Ali and Ibrahim, 2004).

Yersinia enterocolitica is a psychrotrophic organism which was associated with a variety of human illnesses; of which enterocolitis is the most frequent manifestation. The organism has become of considerable public health significance, many outbreaks of food borne infection caused by consumption of contaminated food by the organism, this substantiate the hypothesis reported by (De-Boer et al., 1986). The presence of Yersinia enterocolitica in the examined samples could be attributed to the contamination of the water from which they caught by the organism, and might from the contaminated sewage sludge, this held the view reported by (Langeland, 1983).
Listeria monocytogenes. From the data illustrated in Table (2), it could be concluded that none of the examined samples of Tilapia nilotica, Clarias lazera, frozen Mackerel and smoked Herring was positive for Listeria monocytogenes isolation. Similar results were recorded by (Handa et al., 2005). On the other hand, Listeria monocytogenes was isolated from fresh fish by (Jeyasekaran et al., 2002; ElShenawy, 2006) and in smoked fish by (Alves et al., 2005; Nakamura et al., 2006).

In this respect, EOS, (3494/2005); EOS, (288/2005); EOS, (1-889/2005) recommended that chilled fish, smoked fish and frozen fish, respectively, should be free from Listeria monocytogenes. Therefore, all the examined samples $(100 \%)$ were within the Egyptian limits.

Listeria monocytogenes is a food-borne pathogen associated with neural, visceral and reproductive clinical entities, leading to septicemia, abortions, stillbirth, meningitis and meningoencephalitis, especially in individuals at risk including pregnant women, newborn babies, the elderly, the immunocompromised and persons in contact with animals (Low and Danachie, 1997).

Table (1): Statistical analytical results of microbial counts of different fish samples.

\begin{tabular}{|c|c|c|c|c|}
\hline \multirow[t]{2}{*}{ Parameter } & \multicolumn{4}{|c|}{ Samples } \\
\hline & Tilapia nilotica & Clarias lazera & Frozen Mackerel & Smoked Herring fish \\
\hline $\mathrm{APC}$ at $35^{\circ} \mathrm{C}$ & $5.9 \times 10^{4 b} \pm 1.2 \times 10^{4}$ & $8.8 \times 10^{4 a} \pm 1.4 \times 10^{4}$ & $2.8 \times 10^{4 \mathrm{c}} \pm 3.7 \times 10^{3}$ & $3.9 \times 10^{3 \mathrm{c}} \pm 6.1 \times 10^{2}$ \\
\hline Coli forms (MPN) & $2.8 \times 10^{4} \mathrm{a}_{ \pm} 7.0 \times 10^{3}$ & $4.0 \times 10^{4} \mathrm{a}_{ \pm} .1 \times 10^{3}$ & $4.9^{b} \pm 1.7$ & $0.6^{\mathrm{b}} \pm 0.2$ \\
\hline $\begin{array}{l}\text { Faecal coli forms } \\
\text { (MPN) }\end{array}$ & $2.1 \times 10^{3} b_{ \pm} 5.5 \times 10^{2}$ & $2.0 \times 10^{4} \mathrm{a}_{ \pm} 6.7 \times 10^{3}$ & $1.8^{\mathrm{b}} \pm 1.0$ & $<3.0^{\mathrm{b}} \pm 0.0$ \\
\hline E. coli (MPN) & $1.0 \times 10^{3} b_{ \pm} 3.8 \times 10^{2}$ & $7.8 \times 10^{3} \mathrm{a}_{ \pm} 2.8 \times 10^{3}$ & $0.7^{\mathrm{b}} \pm 0.4$ & $<3.0^{\mathrm{b}} \pm 0.0$ \\
\hline S. aureus & $4.8 \times 10^{2 b} \pm 9.5 \times 10$ & $1.5 \times 10^{3 \mathrm{a}} \pm 3.7 \times 10^{2}$ & $2.4 \times 10^{2} \mathrm{~b} \pm 1.2 \times 10^{2}$ & $1.4 \times 10^{2 b} \pm 2.3 \times 10$ \\
\hline Proteolytic count & $1.2 \times 10^{4 b} \pm 3.4 \times 10^{3}$ & $2.0 \times 10^{4 \mathrm{a}} \pm 3.4 \times 10^{3}$ & $2.3 \times 10^{3 \mathrm{c}} \pm 4.1 \times 10^{2}$ & $2.8 \times 10^{2 \mathrm{c}} \pm 2.0 \times 10$ \\
\hline Lipolytic count & $2.9 \times 10^{4 \mathrm{a}} \pm 7.4 \times 10^{3}$ & $2.7 \times 10^{4 \mathrm{a}} \pm 4.7 \times 10^{3}$ & $2.9 \times 10^{3 \mathrm{~b}} \pm 4.2 \times 10^{2}$ & $3.4 \times 10^{2 b} \pm 5.2 \times 10$ \\
\hline Aeromonas count & $2.6 \times 10^{2 b} \pm 5.6 \times 10$ & $9.9 \times 10^{2 \mathrm{a}} \pm 1.9 \times 10^{2}$ & $9.0 \times 10^{b} \pm 6.1 \times 10$ & $3.3^{b} \pm 3.3$ \\
\hline Pseudomonas count & $5.7 \times 10^{2 b} \pm 1.1 \times 10^{2}$ & $1.9 \times 10^{3 \mathrm{a}} \pm 3.6 \times 10^{2}$ & $3.3 \times 10^{c} \pm 2.1 \times 10$ & $1.3 \times 10^{c} \pm 9.2$ \\
\hline
\end{tabular}

Results expressed by means \pm standard error

APC: aerobic plate count

$a, b$, and c superscripts within each row indicate significant difference at $(p<0.05)$

Table (2): Incidence of isolated microorganisms from muscle samples of examined fishes.

\begin{tabular}{lcccccccc}
\hline Microorganism & \multicolumn{9}{c}{ Sample } \\
\cline { 2 - 8 } & \multicolumn{2}{c}{$\begin{array}{c}\text { Tilapia } \\
\text { nilotica }\end{array}$} & Clarias lazera & $\begin{array}{c}\text { Frozen } \\
\text { Mackerel }\end{array}$ & $\begin{array}{c}\text { Smoked } \\
\text { Herring fish }\end{array}$ \\
\cline { 2 - 8 } & No. & $\%$ & No. & $\%$ & No & $\%$ & No. & $\%$ \\
\hline E. coli (biotype I) & & & & & & & & \\
Staphylococcus aureus (coagulase positive) & 8 & 26.6 & 10 & 33.3 & 2 & 6.6 & 3 & 10 \\
Aeromonas hydrophila & 6 & 20 & 5 & 16.6 & 0 & 0 & 0 & 0 \\
Pseudomonas aeruginosa & 5 & 16.6 & 4 & 13.3 & 0 & 0 & 0 & 0 \\
Yersinia enterocolitica & 7 & 23.3 & 9 & 30 & 5 & 16.6 & 3 & 10 \\
Listeria monocytogenes & 0 & 0 & 0 & 0 & 0 & 0 & 0 & 0 \\
\hline
\end{tabular}




\section{References}

Abdel Rahman, A.A.; Elkamel, A.A.; Neveen, A.H. and Ahmed, S.M. (2004): Hazards associated with the use of chicken manure in fertilization of fish ponds. Assiut Vet. Med. J., 50: 53-65.

Abo El Alla, A.A. (2000): Studies on Aeromonas hydrophila in freshwater fish (Tilapia nilotica and Labeo niloticus) and smoked fishes (herrings) in Assiut governorate. Assiut Vet. Med. J., 43: 200-208.

Agnese, A.P.; Oliveira, V.M.; Silva, P.P.O. and Oliveira, G.A. (2001): Mesophilic aerobic heterotrophic bacterial count and enumeration of total and fecal coli forms in commercial fresh fish in the town of Seropedica, RJ. Higiene Alimentar, 15: 67-70.

Ali, F.H.M. and Ibrahim, M.A. (2004): Hazards resulting from the addition of poultry droppings to the Egyptian semi-intensive aqua cultured Tilapia nilotica fish feeds. Vet. Med. J. Giza., 52: 5-18.

Alves, V.F.; De Martinis, E.C.; Destro, M.T.; Vogel, B.F. and Gram, L. (2005): Antilisterial activity of a Carnobacterium piscicola isolated from Brazilian smoked fish (surubim [Pseudoplatystoma sp.]) and its activity against a persistent strain of Listeria monocytogenes isolated from surubim. J. Food Protect., 68: 2068-2077.

AOAC (Association of Official Analytic Chemists) (1990): Official Methods of analysis. $15^{\text {th }}$ Ed. Inc. USA.

APHA (American Public Health Association) (1992): Compendium of Methods for the Microbiological Examination of Foods. $3^{\text {rd }}$ Ed. Edwards Brothers, Washington D. C., USA.

Bastawrows, A.F.; Abo El Alla, A.A.; Sayed, A.M. and Abd El Sater, M.A. (2000): Microbiological quality of smoked Herring fish in Assiut city. Assiut Vet. Med. J., 43: 110-123.

Basti, A.A.; Ali Misaghi; Salehi, T.Z. and Abolfazl K. (2006): Bacterial pathogens in fresh, smoked and salted Iranian fish. Food Control, 17: 183-188.

Bryan, F.L. (1980): Food borne diseases in the United States associated with meat and poultry. J. Food Prot.; 43: $140-150$.

Davies, A.R.; Cappel, Ch.; Jahanno, D.; Nychas, G.J.E. and Kirby, R.M. (2001): Incidence of food borne pathogens on European fish. Food Control, 12: 67-71.

De-Boer, E.S.; Hartog, B.J. and Osterom, J. (1986): Occurrence of Yersinia enterocolitica in Poultry products. J. Food Protect., 45: 322-325.

El-Akeel, A.T. (1988): Chemical, microbiological and sensory evaluation of hot smoked catfish. Ph. D., Thesis, Fac. Agric., Cairo Univ., Egypt.

El-Atabany, A.I. (1990): Sanitary evaluation of catfish (Clarias lazera) marketed in Zagazig city. Zagazig Vet. J., 18: 126-132.

El-Bakkly, M.I.A. (1997): Quality studies on some local marine fishes as compared with imported Salmon. M.V.Sc., Thesis, Fac. Vet. Med., Cairo Univ.

El-Kelish, H.I. (1990): Staphylococci and Streptococci in Catfish (Clarias lazera) marketed in Zagazig city. Zagazig Vet. J., 18: 153 -175.

El-Shenawy, M.A. (2006): Listeria spp. in the coastal environment of the Aqaba Gulf, Suez Gulf and the Red Sea. Epidemiol. Infect., 134: 752-757.

Eley, A.R. (1992): Microbiological Food Poisoning. Chapman and Hall, London, England.

(EOS) Egyptian Organization for Standardization (2005): Standard Specification for Chilled Fish (3494). Ministry of industry, Egypt.
(EOS) Egyptian Organization for Standardization (2005): Standard Specification For Frozen Fish (1-889). Ministry of industry, Egypt.

(EOS) Egyptian Organization for Standardization (2005): Standard Specification For Smoked Fish (288). Ministry of industry, Egypt.

Fawzy, F.M.; Goda, M.T., Shoman, T.; Nagi, A.; Wassef, N. and Farid, A.F. (1981): Bacteriological examination of Naser lake fish (Tilapia nilotica) sold at Giza and Cairo fish centers. Vet. Med. J., 27: 287-298.

Feldhusen, F. (2000): The role of seafood in bacterial food borne diseases. Microbe Infect., 2: 1651-1660.

Geevarethnam, J.; Ramasamy, A.; Ponesakki, G.; Robinson, J. S. and Duraisamy S. (2008): Microbiological and biochemical quality of grouper (Epinephelus chlorostigma) stored in dry ice and water ice Int. J. Food Sci. Technol., 43: 145-153.

Gonzalez Rodriguez, M.N.; Sanz, J.J.; Santos, J.A.; Otero, A. and Garcia Lopez, M.L. (2002): Numbers and types of microorganisms in vacuum-packed cold-smoked freshwater fish at the retail level. Int. J. Food Microbiol., 77: 161-168.

Handa, S.; Kimura, B.; Takahashi, H.; Koda, T.; Hisa, K. and Fujii, T. (2005): Incidence of Listeria monocytogenes in raw seafood products in Japanese retail stores. J. Food Prot., 68: 411-415.

Hwang, D.F.; Huang, Y.R.; Lin, K.P.; Chen, T.Y.; Lin, S.J.; Chen, L.H. and Hsieh, H.S. (2004): Investigation of hygienic quality and freshness of marketed fresh seafood in Northern Taiwan. J. Food Hyg., Society of Japan, 45: 225230.

ICMSF (International Commission on Microbiological Specifications for Food) (1978): Microorganisms in Foods: Sampling for Microbiological Analysis, Principle and specific application. Univ. of Toronto Press, Toronto, Buffalo, London.

Janda, J.M. (1991): Recent advances in the study of the taxonomy, pathogenicity and infectious syndromes associated with the genus Aeromonas. Clin. Microbiol. Rev., 4: 397- 410.

Jayasinghe, C.V.L.; Jayaweera, V. and Bamunuarachdi (1996): Studies on quality changes of skip jack (Katsy wonuspetomis) and travelly (Carangoides fulvoguttatus) during frozen storage at $-18{ }^{\circ} \mathrm{C}$. FAO Fish. Rep. 563: 591.

Jeyasekaran, G.; Indrani-Karunasagar and Karunasagar, I. (2002): Occurrence of Listeria spp. in processed fishery products. J. Food Sci. Technol., Mysore.; 39: 188-190.

Khalafalla, F.A. (1988): Sanitary status of meat, meat products and fish in Beni-Suef Governorate. Ph. D., Thesis., Fac. Vet. Med., Cairo Univ., Egypt.

Koneman, E.W.; Allen, S.D.; Janda, M.W.; Schreckenberger, P.C. and Winn, C.W. (1994): Diagnostic Microbiology. $6^{\text {th }}$ Ed. JB Lippincott. Philadelphia.

Kumar, A.; Bachhil, V.N.; Bhilegaonakar, K.N. and Agarwal, R.K. (2000): Occurrence of enterotoxigenic Aeromonas species in foods. J. Commun. Dis., 32: 169-174. Langeland, G. (1983): Yersinia enterocolitica and Yersinia enterocolitica like-bacteria in drinking water and sewage sludge. Actapath. Microbiol. Immunol. Scand. Sect. B, 91: 179-185.

Low, J.C. and Donachie, W. (1997): A review of Listeria monocytogenes and listeriosis. Vet. J., 153: 9-29.

Magnusson, H. and Martinsdottir, E. (1995): Storage quality of fresh and frozen-thawed fish in ice. J. Food Sci., 60: 273 . 
Mahmoud, Y.E.A. (1990): Studies on the sanitary condition of some Nile fishes marketed in Kalyobia Governorate. M.V.Sc., Thesis, Fac. Vet. Med. Moshtohor, Zagazig Univ., Egypt.

Mahmoud, Y.E.A. (1999): Quality monitoring of some farm fish marketed in Kafr El-Sheikh Governorate. Assiut Vet. Med. J., 41: 152-161.

Martins, C.V.B.; Vaz, S.K. and Minozzo, M.G. (2002): Health aspects of fish sold at fish markets in Toledo, Parana. Higiene Alimentar, 16: 51-56.

Nakamura, H.; Tokuda, Y.; Sono, A.; Koyama, T.; Ogasawara, J.; Hase, A.; Haruki, K. and Nishikawa, Y. (2006): Molecular typing to trace Listeria monocytogenes isolated from cold-smoked fish to a contamination source in a processing plant. J. Food Prot., 69: 835-841.

National Academy of Science (1985): An Evaluation of the Role of Microbiological Criteria For Foods and Food Ingredients. National Academy Press., Washington, D.C., USA.

Pacheco, T.D.A.; Leite, R.G.M.; Almeida, A.C.D.; Silva, N.D.M.O. and Fiorini, J.E. (2004): Analysis of coli forms and mesophilic bacteria in freshwater fish. Higiene Alimentar, 18: 68-72.

Papadopoulou, C.; Economou, E.; Zakas, G.; Salamoura, C.; Dontorou, C. and Apostolou, J. (2007): Microbiological and pathogenic contaminants of seafood in Greece. J. Food Quality, 30: 28-42.

Pensrie, R.; Tanongpan, S. and Patcharaporn, S. (1991): Study on Staphylococcus aureus in frozen food products. J. Food Technol, 21: 197.

Pereira, M.L.; de Carmo, L.S.; dos Santos, E.J. and Bergdoll, M.S. (1994): Staphylococcal food poisoning from cream-filled cake in metropolitan area of SouthEastern Brazil. Revista de Saude Publica; 28 : 406-409.
Pireson, M.D.; Thompson, D.L.C. and Ordal, Z.J. (1970): Microbiological, sensory and pigment changes of aerobically and an aerobically packaged beef. J. Food Technol., 24: 1171.

Radu, S.; Ahmad, N.; Ling, F.H. and Reezal, A. (2003): Prevalence and resistance to antibiotics for Aeromonas species from retail fish in Malaysia. Int. J. Food Microbiol., 81: 261-266.

Rodma, P.; Satjapala, T. and Suwanvitaya, P. (1991): Staphylococcus aureus occurrence in frozen foods. Food, 21: 197-204.

Silva, M.C.D.; Normande, A.C.L.; Ferreira, M.V.; Ramalho, L.S. (2002): Evaluation of the microbial quality of fish sold in Maceio, AL. Higiene Alimentar, 16: 60-64.

Sivertsvik, M.; Jeksrud, W.K. and Rosnes, J.T. (2002). A review of modified atmosphere packaging of fish and fishery products - significance of microbial growth, activities and safety. Int. J. Food Sci. Technol., 37: 107127.

Thayumanavan, T.; Vivekanadhan, G.; Savithamani, K.; Subashkumar, R. and Lakshmanaperumalsamy, P. (2003): Incidence of haemolysin-positive and drug-resistant Aeromonas hydrophila in freshly caught finfish and prawn collected from major commercial fishes of coastal South India. FEMS Immunol. Med. Microbiol., 36: 41-45.

Tzikas, Z.; Amvrosiadis, I.; Soultos, N. and Georgakis, S. (2007): Seasonal variation in the chemical composition and microbiological condition of Mediterranean horse mackerel (Trachurus mediterraneus) muscle from the North Aegean Sea (Greece). Food Control, 18: 251-257.

Youssef, H.; El-Timawy, K. and Ahmed, S. (1992): Role of aerobic intestinal pathogens of fresh waster fish in transmission of human diseases. J. Food Prot., 55: 739-740.

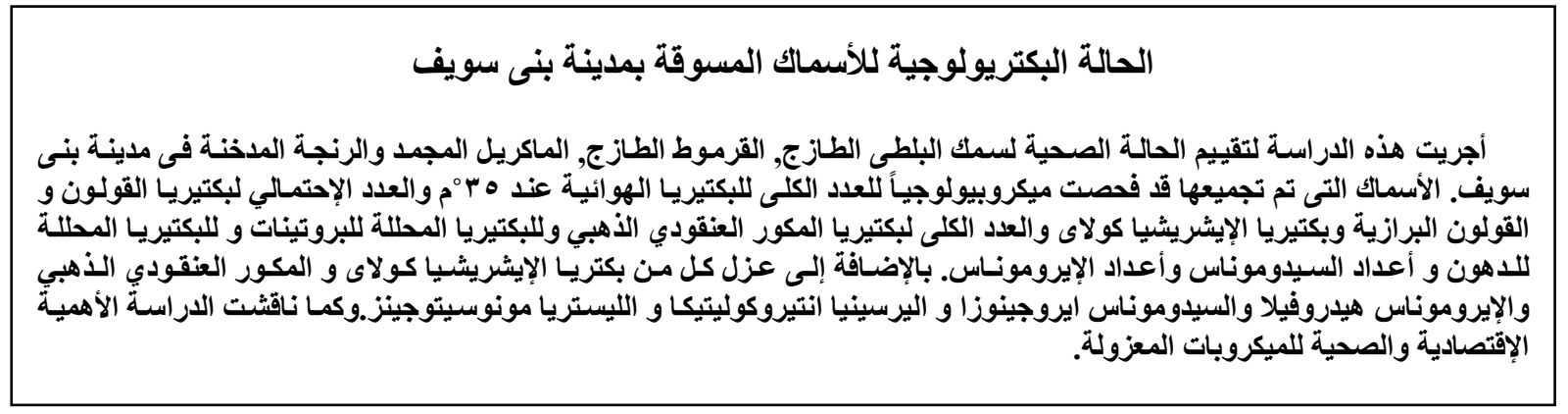

